\title{
Investigating cross-contamination of aquifers
}

\author{
Paul M. Santi · John E. McCray · Jamie L. Martens
}

\begin{abstract}
Shallow aquifers can cross-contaminate deeper aquifers through penetration of an intervening aquitard, via sandy intervals in the aquitard, along well casings, across long well screens, or around aquitard pinchouts. Distinguishing among these potential pathways requires the use of evaluation tools that may support or eliminate certain pathways. These tools include groundwater gradient and aquitard penetration calculations, aquifer pumping test interpretation techniques, chemical concentration plots and statistical methods, hydraulic conductivity-based travel time calculations, pumping-concentration tests, methods for evaluating leaky wells, and methods for evaluating aquitard continuity. Based on analysis of several of these techniques at three sites experiencing aquifer cross-contamination, the authors conclude that calculation of flow rates for various pathways is the single most useful method to confirm or refute specific pathways. Evaluation of leaky wells and aquitard continuity generally must be coupled with other tools to adequately test specific pathways. While fingerprinting, statistical analysis or ratio analysis of contaminants from various sources and receptors was not completed for any of the evaluated sites, the authors believe that these techniques have strong potential for confirming or eliminating pathways. Future research in this area is suggested. Furthermore, the interpretation of pumping-con-
\end{abstract}

Received: 2 November 2004 / Accepted: 26 November 2004 Published online: 26 January 2005

(C) Springer-Verlag 2005

P. M. Santi (

Department of Geology and Geological Engineering, Colorado School of Mines,

Golden, CO, 80401, USA

e-mail: psanti@mines.edu

Tel.: +1-303-2733108

Fax: +1-303-2733859

J. E. McCray

Division of Environmental Science and Engineering,

Colorado School of Mines,

Golden, CO, 80401, USA

J. L. Martens

URS Corporation,

Suite 100, 10975 El Monte, Overland Park, KS, 66211, USA centration tests is not well developed and needs further assessment.

Résumé Les aquifères de surface peuvent contaminer les aquifères plus profonds à travers un aquitard, un intersection sableuse dans l'aquitard, le long des forages et de leur crépines, ou de la terminaison biseautée des aquitards. Distinguer et sélectionner ces différents modes de contamination nécessite l'utilisation d'outils d'évaluation. Ces outils incluent le gradient d'écoulement des eaux souterraines et le calcul de pénétration des aquitards, les techniques d'interprétation des essais de pompage, les méthodes d'interprétation chimiques et de traitement statistique, les calculs des temps de transferts sur base de la conductivité, les tests de pompage couplé aux analyses de concentration, les méthodes pour évaluer l'infiltration directe alimentant les forages, et les méthodes permettant d'évaluer la continuité des aquitards. Basé sur l'analyse de plusieurs de ces techniques sur trois sites expérimentales présentant des contaminations transversale, les auteurs concluent que le calcul des rapports d'écoulement est la méthode la plus simple pour confirmer ou refuser les voies spécifiques. Alors que le traçage, les analyses statistiques et les analyses de la contamination provenant de différentes sources et récepteurs n'était pas complètes pour la plus part des différents sites évalués n'étaient pas compléments certains, les auteurs croient que ces techniques ont un potentiel fort pour confirmer ou éliminer ces techniques. Des recherches futures dans cette zone est suggérée. Par ailleurs, l'interprétation des tests de pompage couplés à l'analyse des concentrations n'est pas développée et nécessite de meilleurs estimations.

Resumen Acuíferos someros pueden ocasionar contaminación transversal de acuíferos profundos mediante la penetración de un acuitardo intermedio, a través de intervalos arenosos en el acuitardo, a lo largo del revestimiento de pozos, o en las inmediaciones de lentes de acuitardos. Para distinguir entre estas trayectorias potenciales se requiere el uso de herramientas de evaluación que pueden apoyar o eliminar ciertas trayectorias. Estas herramientas incluyen cálculos de gradientes de agua subterránea y penetración de acuitardos, técnicas de interpretación de pruebas de bombeo de acuíferos, diagramas de concentración química y métodos estadísticos, estimaciones de conductividad hidráulica en base al tiempo de viaje, 


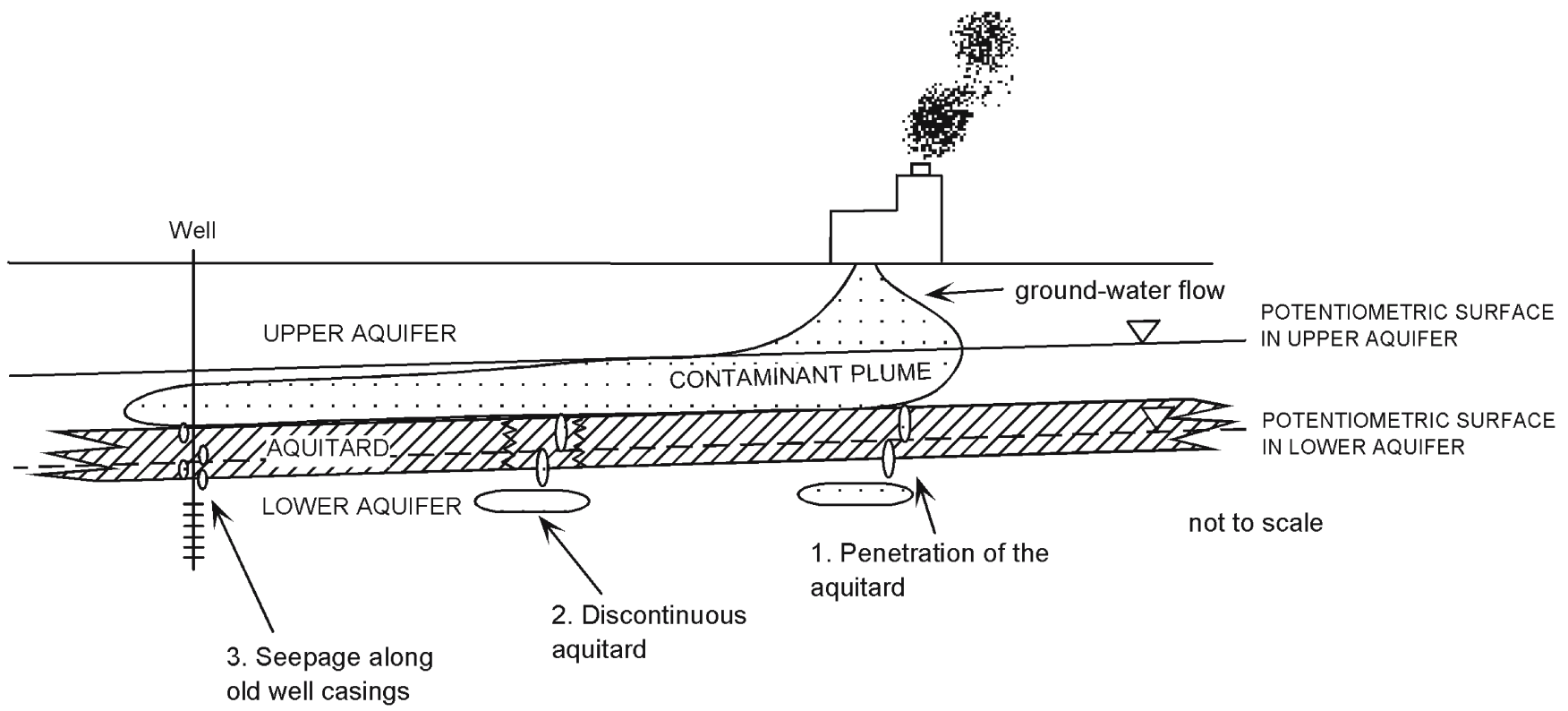

Fig. 1 Aquifer cross-contamination pathways through an intervening aquitard. In this case there is a downward gradient from the upper aquifer to the lower aquifer

pruebas de concentración de bombeo, métodos para evaluar pozos con fugas, y métodos para evaluar la continuidad de acuitardos. Basándose en el análisis de varias de estas técnicas en tres sitios que experimentan contaminación transversal de acuíferos, los autores concluyen que la estimación de ritmos de flujo para varias trayectorias es el único método más útil para confirmar o rechazar trayectorias de flujo específicas. La evaluación de pozos con fugas y continuidad de acuitardos generalmente debe estar acompañada con otras herramientas para probar adecuadamente trayectorias específicas. Aunque no se completó para ninguno de los sitios evaluados técnicas de huellas, análisis estadístico o análisis de relaciones de contaminantes de varias fuentes y receptores, los autores creen que estas técnicas tienen fuerte potencial en la confirmación o eliminación de trayectorias. Se sugiere investigación futura en esta área. Además, la interpretación de pruebas de concentración de bombeo no se ha desarrollado bien y necesita evaluación posterior.

Keywords Confining units - Contamination - General hydrogeology · Groundwater flow · Groundwater protection

\section{Introduction}

A common community drinking-water supply is a lower drinking-water aquifer separated from an upper unconfined aquifer by a low-permeability aquitard. When the drinking-water aquifer is discovered to be contaminated, the chemical pathway is usually via a discontinuity in the aquitard, which allows communication with a contaminated upper aquifer. These discontinuities typically fall into three categories: natural breaks or "holes" in the aquitard, man-made "holes" through the aquitard (e.g., from a well bore), or complete pinchout of the aquitard. For aquifer restoration, as well as for assignment of liability, it is important to identify which of these pathways is the source of contamination.

The purpose of this paper is to assemble and demonstrate some tools available for analysis of aquifer crosscontamination, with the goal of identifying the likely flow paths of contaminants. Each analysis tool will be described in detail and the potential use of each tool for pinpointing a specific flow path will be summarized. Finally, three case histories will be presented using the tools to interpret site hydrogeology.

\section{Potential cross-contamination paths}

When groundwater contamination of the lower aquifer in a multi-aquifer system occurs, three mechanisms for cross-contamination are generally proposed. These mechanisms are shown schematically on Fig. 1:

1. Penetration of an aquitard: in this case, contaminants have traveled through the aquitard separating the two units. Specific chemicals may alter the hydraulic properties of an aquitard to accelerate this process.

2. Discontinuous aquitard: minor discontinuities in aquitards, such as gradational sandy zones or coarse channel deposits, can create significant avenues for contaminant migration.

3. Seepage along well casings: seals along well casings, particularly in older wells, may be imperfect.

As less common, yet equally important mechanism for lower aquifer contamination has also been documented: 


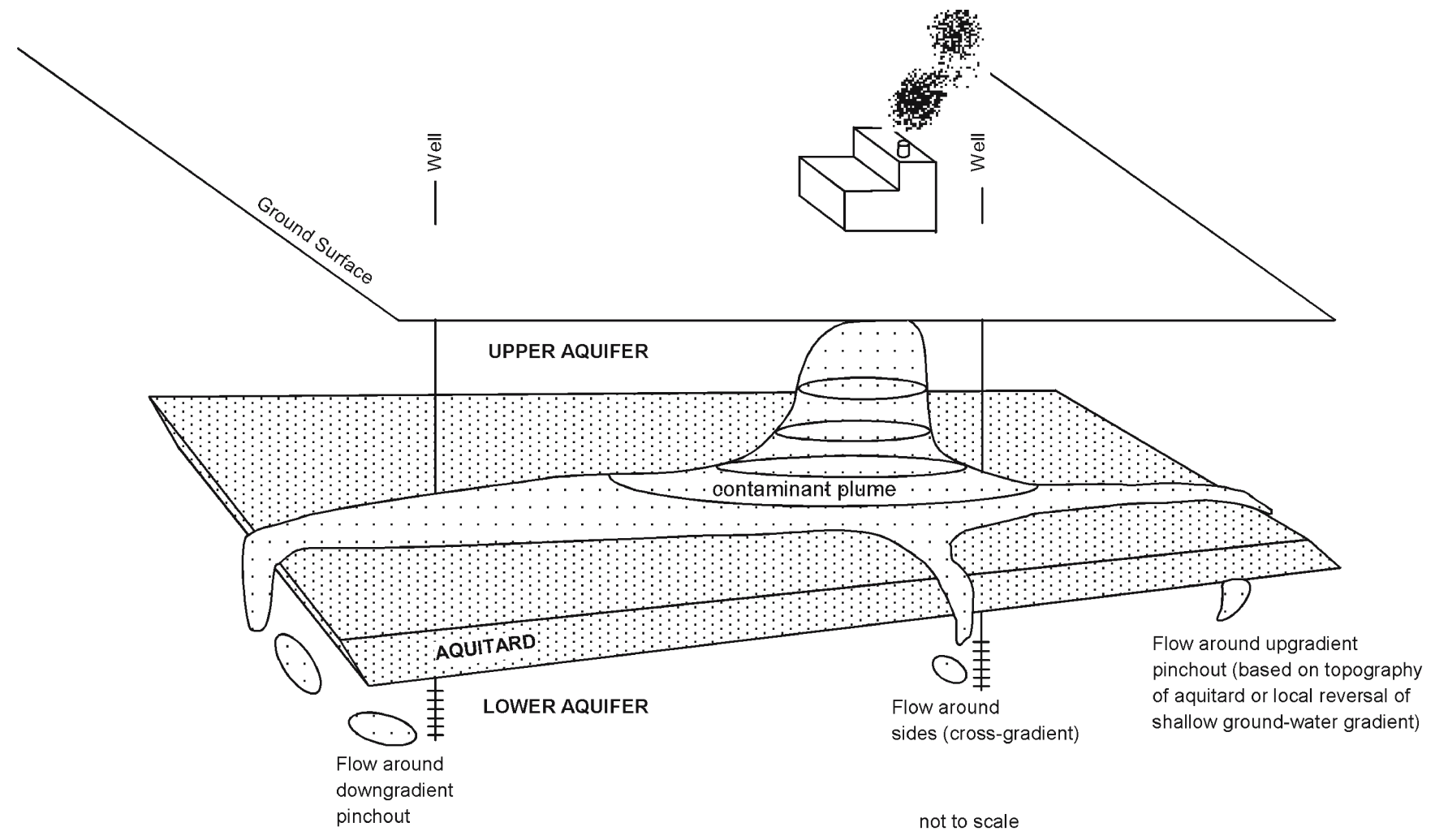

Fig. 2 Examples of aquifer cross-contamination pathways around aquitard pinchouts. In all three directions shown, contaminant movement depends on favorable local gradients in the upper aquifer

4. Aquitard pinchout and flow reversal: in this case, natural aquitard pinchout allows mingling of contaminated upper aquifer groundwater with clean lower aquifer groundwater. Pumping from lower aquifers for water supply accelerates or reverses natural groundwater gradients, which exacerbates cross-contamination and causes contaminant plume migration into areas that may not have been anticipated. This mechanism is shown schematically on Fig. 2, where contamination from the upper aquifer may come from upgradient, downgradient, or crossgradient of aquitard pinchouts.

An example of Mechanism 4 is described in Bethune et al. (1996), who analyzed contamination of a water supply lake induced by reversal of groundwater flow through heavy pumping. They were able to distinguish between two possible sources of lake contamination resulting from the change in groundwater flow by using principles of inorganic and organic chemistry, piezometric cross-sections, and capture-zone modeling.

Mechanism 4 is also supported by data in this paper from sites at Fort Ord and Merced, California, and from a site in the central U.S. Methods of evaluating sources of cross-contamination of aquifers are reviewed, followed by application of some of these methods to interpret contaminant sources at each site. and gradients toward the contaminated wells in the lower aquifer. Each of these flow pathways is documented in a case study later in the paper

\section{Potential evaluation methods}

Numerous evaluation methods are available to confirm contamination sources and flowpaths. The application of these methods is summarized below, and the following section provides guidance on the use of each method to confirm suspected cross-contamination mechanisms.

\section{Groundwater gradients and aquitard penetration}

One of the strongest arguments against contamination of a lower aquifer from an upper aquifer would be demonstration of an upward vertical groundwater gradient. A notable exception to this is the downward movement of dense non-aqueous phase liquids (DNAPLs), where the density gradient works against groundwater flow. The higher density of a DNAPL pool, compared to fresh water, may be represented as an increased equivalent head (Lusczynski 1961) as represented by the following equation:

$\mathrm{h}_{\text {dnapl }}=\mathrm{h}_{\mathrm{w}} *\left(\rho_{\text {dnapl }} / \rho_{\mathrm{w}}\right)$

where $\mathrm{h}_{\mathrm{dnapl}}=$ equivalent head of the DNAPL pool in the upper aquifer, $h_{w}=$ water head in the upper aquifer, $\rho_{\text {dnapl }}=$ density or unit weight of the DNAPL compound, $\rho_{\mathrm{w}}=$ density or unit weight of water. If the groundwater gradient is weak, downward flow will be produced if the 
A. Upward gradient

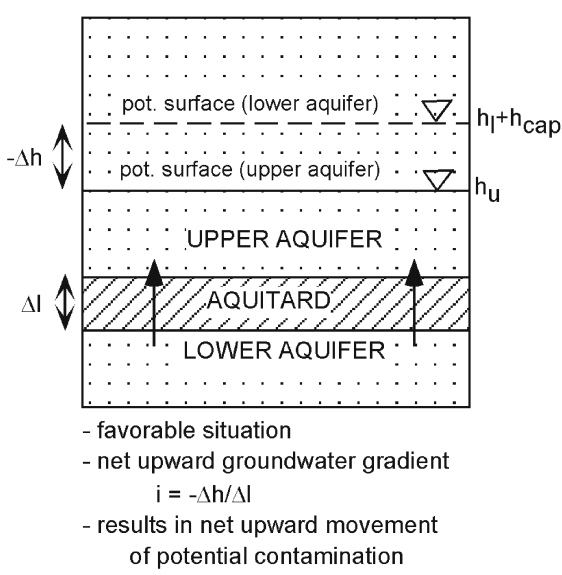

B. Downward gradient

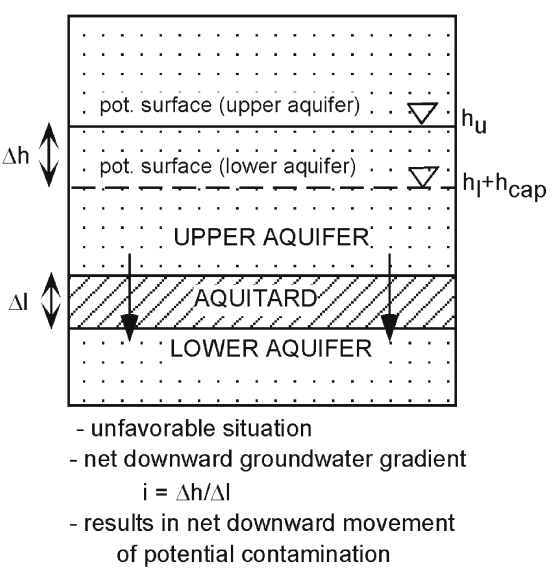

C. DNAPL-induced downward gradient

Fig. 3A-C Example showing the effects of vertical ground-water gradients and equivalent head of DNAPL pools on migration of contaminants into a lower aquifer

DNAPL head exceeds the capillary resistance of the aquitard:

$\mathrm{h}_{\mathrm{dnapl}}=2\left(\cos _{\gamma}\right) \sigma_{\mathrm{nw}} / \mathrm{r}_{\mathrm{eff}} \mathrm{gh}=\mathrm{h}_{\mathrm{cap}}$

where $\mathrm{h}_{\mathrm{cap}}=$ capillary head developed in the clay, $\gamma=$ wetting angle (often assumed to be $0^{\circ}$, so $\cos \gamma=1$ ), $\sigma_{\mathrm{nw}}=$ NAPL-water interfacial tension (may be obtained from Mercer and Cohen 1990), $\mathrm{r}_{\text {eff }}=$ effective pore radius of aquitard (may be estimated by $\mathrm{d}_{50} / 8$, see Mercer and Cohen 1990).

The capillary resistance is usually negligible in sands. If the groundwater gradient is strong, downward flow will be produced only if the DNAPL head exceeds both the capillary head and the groundwater gradient head:

$\mathrm{h}_{\text {dnapl }}=2\left(\cos _{\gamma}\right) \sigma_{\mathrm{nw}} / \mathrm{r}_{\mathrm{eff}} \mathrm{gh}=\mathrm{h}_{\mathrm{l}}$

where $h_{l}=$ water head in the lower aquifer.

The effects of the equivalent head are shown in Fig. 3. In Fig. $3 \mathrm{~A}$, the head in the lower aquifer, $h_{1}+h_{\text {cap }}$, is greater than the head in the upper aquifer, $h_{u}$. The resultant upward gradient between the two aquifers inhibits downward migration of contaminants.

In Fig. 3B, the head in the lower aquifer is now less than that in the upper aquifer, resulting in a downward groundwater gradient and potential downward migration of contaminants.

The measured heads in Fig. $3 \mathrm{C}$ are the same favorable arrangement as in Fig. 3A, with the lower aquifer showing higher head than the upper aquifer. However, the high density DNAPL pool in the upper aquifer results in an equivalent head higher than that in the lower aquifer. The net gradient is then downward, as in Fig. 3B. The travel time of the DNAPL through the aquitard also depends on the hydraulic conductivity of the aquitard, which may be very slow.

The previous approach (using Eqs. 1 and 3) may also be applied to dense aqueous phase liquids (DAPLs).
However, because DAPLs are miscible with water, $\sigma_{\mathrm{nw}}=0$, and there is no capillary tension associated with an aquitard.

\section{Pumping tests}

Significant transfer of contaminants from an upper to a lower aquifer will manifest itself as leakage to the lower aquifer during a pumping test. A schematic example of these effects is shown on Fig. 4, using a pumping well, two wells in the upper aquifer (U1 and U2) and two wells in the lower aquifer (L1 and L2).

In Fig. 4A, no leakage through the aquitard occurs. In Fig. 4B, the entire aquitard is leaky, and both the pumping and lower aquifer observation wells show slightly less drawdown than that predicted, because additional water is supplied through the aquitard (Neuman and Witherspoon 1969, 1972). In Fig. 4C, leakage through the aquitard is concentrated in one area, such as where the aquitard grades sandy, or in areas where it thins, pinches out, or is fissured.

\section{Chemical concentrations}

Comingling of water from different sources has traditionally been represented graphically. Figure 5 is an idealized example using a Stiff plot, but for site-specific contaminants, which will be referred to as "indicator" chemicals, rather than the ionic species normally plotted. In this example groundwater at Well A is contaminated with chlorinated solvents (primarily TCE and PCE, and their degradation products). The contaminants move towards Wells $C$ and E, whose Stiff plots show slight dilution of the contaminants. Ideal indicator chemicals should be non-reactive and conservative, so that their concentrations and concentration ratios may be assumed to be entirely a function of original concentration modified by dilution or mixing. Mixing, dilution, and reaction of chemicals can be modeled with groundwater chemistry computer models such as PHREEQC. 
A. No leakage
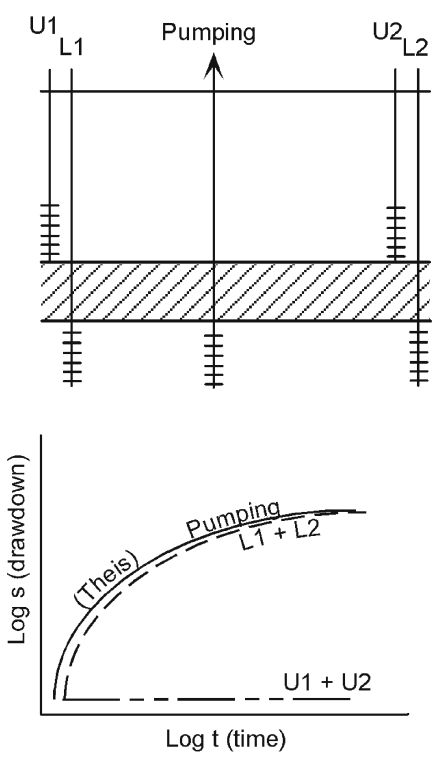

a.

- no observed response in upper aquifer

- very slight time lag between

pumping initiation and

response in deep

observation wells
B. Evenly distributed leakage
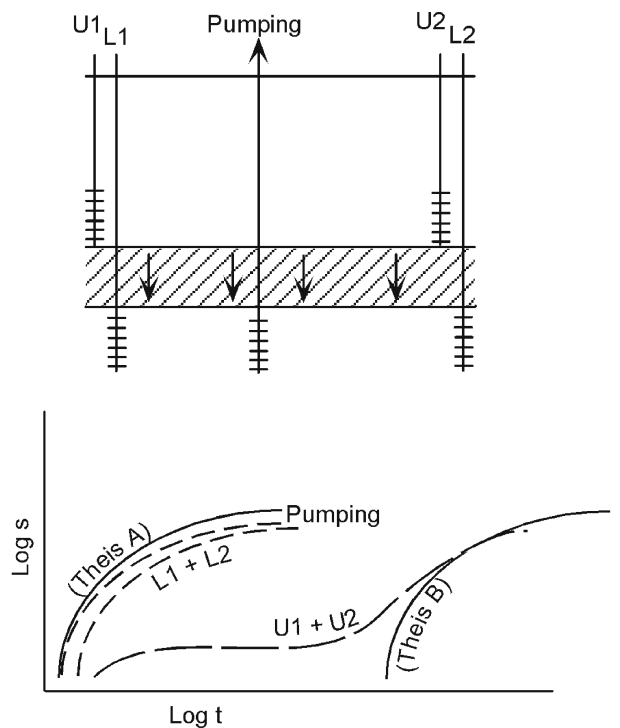

b.

- leakage is strongest near pumping well where drawdown in the lower aquifer is the greatest

- pumping and lower aquifer wells show less drawdown than expected

- upper aquifer wells show effects of vertical water flow (the example here shows this as divergence from the Theis A curve)
C. Unevenly distributed leakage
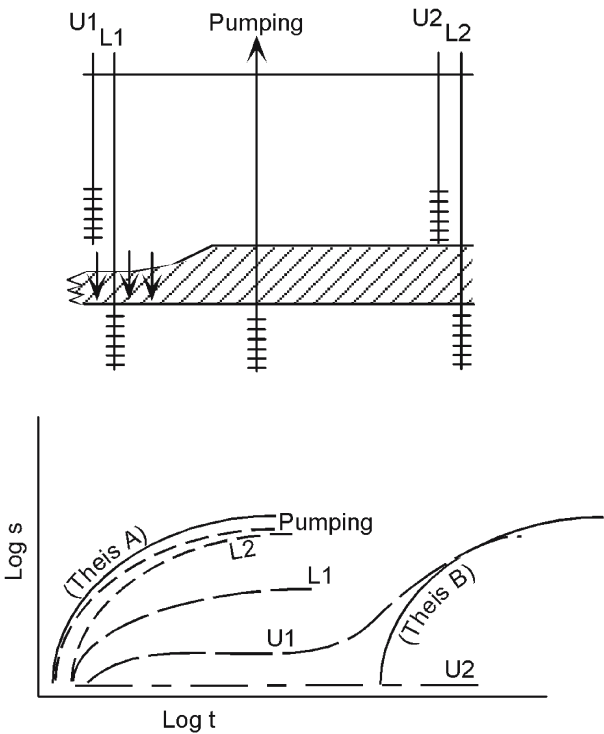

c.

- L1 and U1 show effects of leakage: L2 and U2 do not - this is also the expected response if the aquitard pinches out near wells L1 and U1

Fig. 4A-C Example showing the effects of leakage on aquifer pumping test results

Fig. 5 Idealized Stiff plot using indicator chemicals instead of cations and anions. In this case, Well A is contaminated, and the effects of this contamination, with a degree of dilution is shown progressively in Wells C and E. Lower aquifer Wells B and $\mathrm{D}$ are unaffected

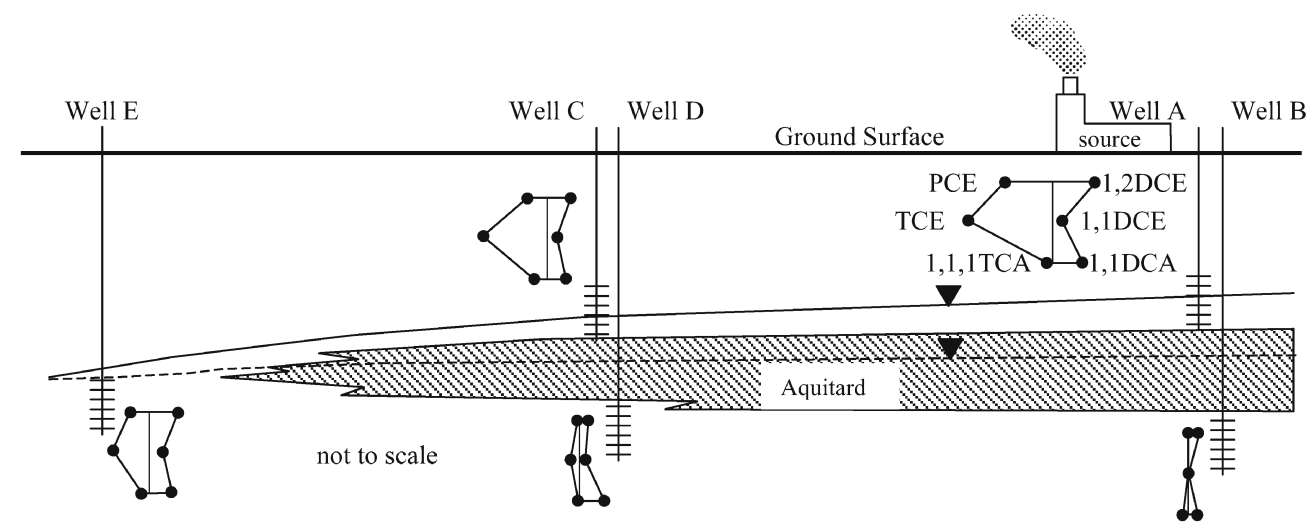

Several examples of this type of analysis may be found in the technical literature. For instance, Mariner et al. (1997) distinguish between two possible sources of arsenic contamination in sediments in a waterway by noting correlations of arsenic concentrations with other metals concentrations $(\mathrm{Pb}, \mathrm{Cu}$, and $\mathrm{Zn})$ that are similar to the arsenic/metals correlations for one source of contamination but not the other.

Fingerprinting groups of chemicals is useful to distinguish between multiple sources of contaminants or multiple contaminated aquifers. For example, Douglas and McMillen (1996) developed a detailed testing and inter- pretive strategy to fingerprint petroleum hydrocarbons in soil. Zemo et al. (1995) use characteristic GC/FID traces to fingerprint multi-compound petroleum hydrocarbons, including gasoline, diesel fuel, and bunker and motor oil. Hydrocarbons that have "weathered" due to volatilization or biodegradation may also be fingerprinted and distinguished from their parent sources. Powers et al. (1997) use four-axis star plots (a type of radar graph) to represent several types of weathered and unweathered hydrocarbons.

Statistical clustering techniques for classification of water samples into hydrochemical facies (Back 1966) to define groundwater flow paths have been used in the past 


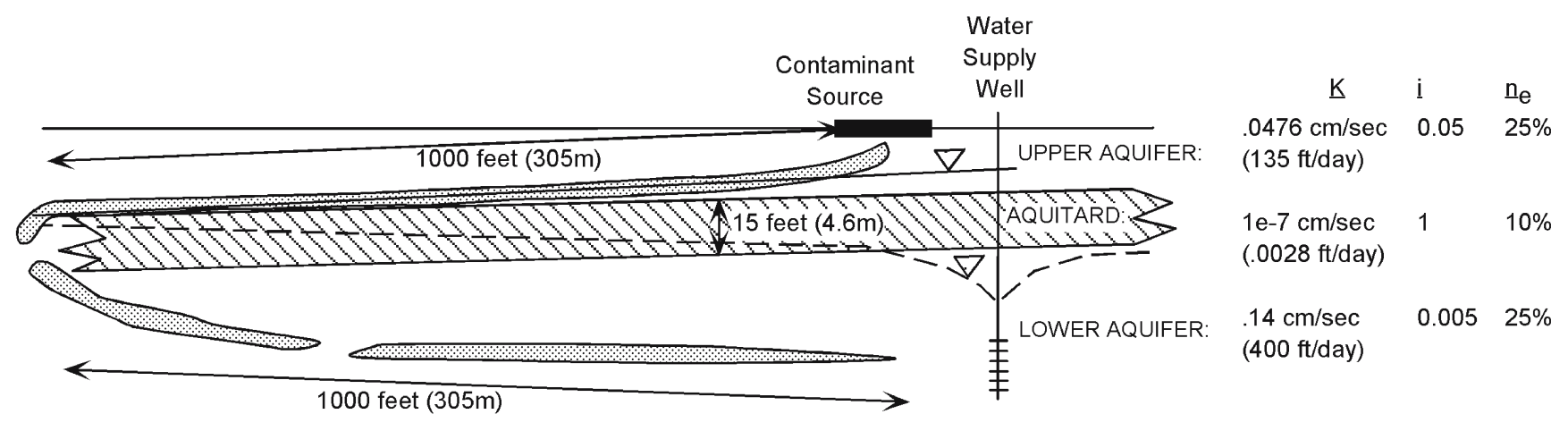

not to scale

Fig. 6 Information required for travel time calculation to evaluate potential contaminant flow paths. Data for this example is from the Mid-Western U.S. site analyzed later in the paper

for inorganic parameters (Jaquet et al. 1975; Alther 1979; Williams 1982; Farnham et al. 2000). For instance, Güler et al. (2002) found that statistical clustering techniques for inorganic water-chemistry parameters significantly improved on traditional graphical fingerprinting of water masses. They concluded that statistical clustering is not only more objective and robust than typical visual plotting methods, but can also incorporate more data into the analysis.

\section{Hydraulic conductivity arguments}

Calculation of travel time and solute concentrations depends strongly on hydraulic conductivity. Figure 6 is an example case where the expected travel time is calculated from an upper aquifer source, around an aquitard pinchout, to a lower aquifer well (using data from the Midwestern U.S. site described in more detail later in the paper). As is sometimes the case, the flow direction in the lower aquifer has been reversed because of long-term pumping from the water supply well (examples of this situation are discussed in the "Case Studies" section).

Using Darcy's Law and the values given in Fig. 6, the expected travel time around the aquitard pinchout is 162 days or roughly 0.5 years. The expected travel time for water to penetrate the aquitard is 536 days or roughly 1.5 years. In this case, the two pathways could be distinguished based on travel time alone. Diffusive effects, which are not included in this calculation, could significantly increase contaminant transport and shorten travel time.

If the contaminant is a DNAPL, such as TCE, the effective hydraulic conductivity of the aquitard may actually be higher or lower, depending on the fluid density and viscosity, as well as the relative volumes of DNAPL and water in the pore spaces:

$K=\frac{k * k_{r e l} * \rho * g}{\mu}$

where $K=$ hydraulic conductivity of the aquitard for a given fluid (which may or may not be fresh water), $k_{\text {rel }}=$ permeability adjustment factor caused by presence of
NAPL (less than one), $\rho=$ density of the fluid, $g=$ acceleration of gravity, $\mu=$ viscosity of the fluid. Values for $\rho$ and $\mu$ for various DNAPLs can be obtained from Mercer and Cohen (1990).

Based on this equation, the hydraulic conductivity experienced by a DNAPL, $\mathrm{K}_{\mathrm{dnapl}}$, may be shown to be

$\mathrm{K}_{\text {dnapl }}=\mathrm{K}_{\text {water }} *\left(\rho_{\text {dnapl }} / \rho_{\text {water }}\right) *\left(\mu_{\text {water }} / \mu_{\text {dnapl }}\right) * \mathrm{k}_{\text {rel }}$

For the example shown on Fig. 6, the travel time through the aquitard is expected to be accelerated, provided the fraction of pore space filled by DNAPL is high, because TCE is more dense and less viscous than water and will therefore travel more easily through the aquitard.

As an example of the influence of the density, viscosity, and relative permeability of a DNAPL on its rate of flow, consider a plume of TCE (1.46 times as dense and 0.57 times as viscous as water at $20^{\circ} \mathrm{C}$ ). Using relative permeability numbers for TCE from Lin et al. (1982), the following values for TCE are calculated:

\begin{tabular}{lll}
\hline \% TCE saturation & $\mathrm{k}_{\mathrm{rel}}$ for TCE & $\mathrm{K}_{\mathrm{TCE}}$ \\
\hline 100 & 1.0 & $2.6 \times \mathrm{K}_{\text {water }}$ \\
95 (estimated) & 0.9 & $2.3 \times \mathrm{K}_{\text {water }}$ \\
60 & 0.4 & $1.0 \times \mathrm{K}_{\text {water }}$ \\
40 & 0.2 & $0.5 \times \mathrm{K}_{\text {water }}$ \\
\hline
\end{tabular}

These calculations show that TCE will move faster than water for TCE saturations in excess of $60 \%$ and slower than water for saturations less than $60 \%$.

The distinction between free-phase DNAPL and lower levels of saturation is an important one. Calculation of hydraulic conductivity at intermediate saturations or for multi-phase flow is more complicated than for free-phase fluids, and examples of these calculations may be found in Faust (1985), Abriola and Pinder (1985), Kueper and Frind (1991), Oolman et al. (1995), McCray and Falta (1997), and Fetter (1999). 


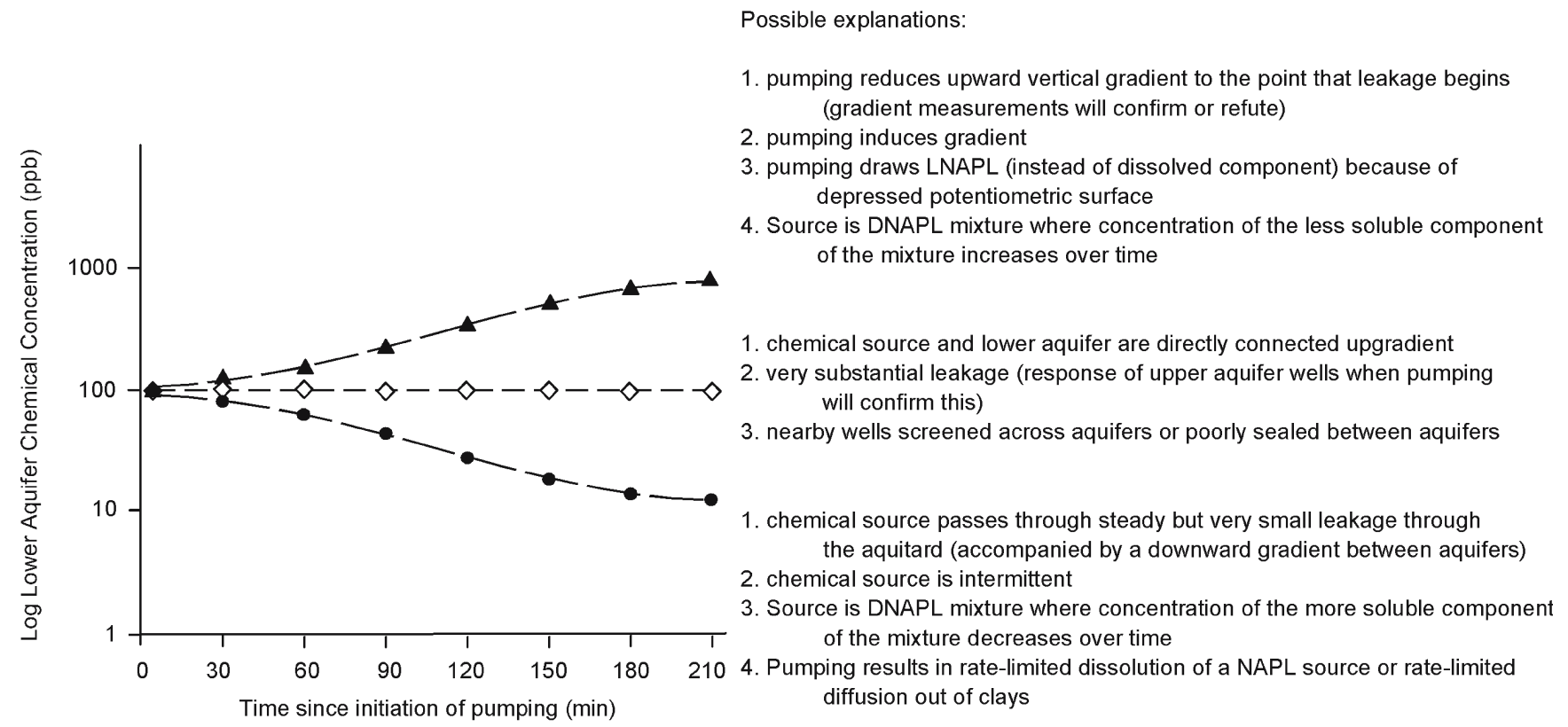

Fig. 7 Idealized results from a pumping-concentration test

\section{Changes in concentration of contaminants during pumping}

A pumping-concentration test may also be used to distinguish between possible contaminant sources. Such a test is performed by sampling aquifer water and testing chemical concentrations before pumping, and then sampling and testing at specified intervals after pumping begins. Possible test interpretations are suggested for an idealized case in Fig. 7, where a pumping well is in a different aquifer from the main source of contaminants and the primary contaminant plume.

Locke (1994) notes the importance of stratification of concentrations of ion species within an aquifer, and evaluates the changes in concentrations with pumping for both the pumping well and an observation well. He concludes that the greatest concentration changes occurred in or directly adjacent to the screened interval, and the smallest changes occurred at the base of the aquifer. Some ion species increased with pumping, some decreased, and some did not show a trend in either direction.

For long periods of pumping, greatly in excess of that shown on Fig. 7, a concentration decrease is expected, regardless of the contaminant travel path. This is the result typically observed in pump-and-treat programs for groundwater remediation, where chemical concentrations are dominated by rate-limited dissolution of NAPL sources, rate-limited diffusion out of contaminated clay zones, or preferential removal of more soluble components in NAPL mixtures.

\section{Evaluation of leaky wells}

Old wells or wells for which installation information is incomplete are common scapegoats for aquifer crosscontamination because of improper backfill or screening across multiple water-bearing zones. Fryberger and Tinlin (1984) estimate that the United States alone has nearly two million abandoned wells. Examples of groundwater contamination caused by abandoned wells are given in Gass et al. (1977), and examples of methods of detection are given in Javandel et al. (1988) and Aller (1984). Lacombe et al. (1995) present fluid flow and solute transport algorithms, as well as groundwater modeling results for leaky boreholes in the same idealized setting discussed in this paper: an upper unconfined aquifer, a middle aquitard, and a lower confined aquifer.

Improper backfill and screened intervals of wells may be identified with logs or completion diagrams or by using video logs of wells. Evaluation of open-hole sections can be done by video or by using Borehole Image Processing (BIPS). The Acoustic Borehole Televiewer has similar capabilities, and is effective through muddy water, since it relies on sonic waves rather than light waves (Welenco 1995). Casing leakage and upward or downward water flow may be detected using temperature, flowmeter or hydrophysical (conductivity) logs.

A geophysical Cement Bond Log (CBL) may be used to gauge the quality of the bonding of cement grout to the outside of a steel or PVC well casing (Welenco 1995). The CBL relies on the difference in sonic velocities between cement and void space or unconsolidated formation materials and it will also detect casing perforations as a low amplitude signal (Welenco 1995).

Tracer tests can be used to evaluate leakage through annular backfill at the ground surface or interconnection between aquifers via unknown screened intervals. For instance, Meiri (1989) describes the use of a sodium bromide tracer to confirm leakage from an upper unconfined aquifer through a clay aquitard, and into a lower 
confined aquifer via a poorly constructed well completed in the lower aquifer.

If the appropriate wells are available, pumping tests can evaluate the "leaky" condition induced by leakage along the well casing or through multiple screened intervals. The ideal arrangement would be to have at least one shallow aquifer well and one deep aquifer well flanking the suspect well. If leakage is detected, then the magnitude and rapidity with which it becomes apparent may be used to distinguish between the three possible cases: (1) natural leakage through the aquitard (low leakage rates, delayed occurrence), (2) leakage along the well annulus (moderate leakage rates, moderately rapid occurrence), or (3) leakage through a well screen that extends through both aquifers (high leakage rates, rapid occurrence).

\section{Aquitard continuity}

Aquitards may be ineffective where they are thin, pinched-out, intermittently absent, or graded with coarser material. Tools for detecting these features might include exploratory borings, cone penetrometer studies, geophysical surveys, and geologic analysis of depositional environments. Examples of the use of geophysical tools are presented below.

Lindenberg (1997) evaluates the use of Ground Penetrating Radar (GPR) to assess aquitard continuity at a TCE contaminated site. She used $50 \mathrm{MHz}$ and $200 \mathrm{MHz}$ frequencies, and achieved good resolution to depths of up to $16 \mathrm{~m}$, but with imperfect correlation to geology. She concludes that more sophisticated migration and filtering processes will improve the geologic interpretation and correlation, and lower frequency antennas will provide deeper penetration, albeit with less resolution.

Cardimona et al. (1998) use both shallow seismic reflection and GPR to image the sand-clay interface at the base of a shallow unconfined aquifer (10-14 m depth). They confirmed their interpretations with cone penetrometer soundings. They note that although it is challenging to obtain good seismic reflection data at such shallow depths, correlation with GPR data strengthens the interpretations. However, they also warn that it is uncommon to get good data from one site for seismic methods, which favor wet, clayey soils, and GPR methods, which favor dry, sandy soils (Clement et al. 1997). Neither data set provided a good image of the water table, probably a result of a large capillary fringe above the true water table.

Moore (1991) describes the use of electrical resistivity techniques to develop an isopach map of a shallow clay aquitard. The generated map was calibrated against information from 168 boreholes.

\section{Matching evaluation methods to paths}

Table 1 summarizes the evaluation methods and the travel paths each method may support or disprove. Many of these methods are non-unique; that is, a specific result may support more than one potential travel path, although several others may be eliminated. For this reason, several methods should be used in conjunction to identify the most likely travel path.

\section{Case studies}

Three case studies are presented to demonstrate the application of the evaluation tools using typical data collected during remedial investigations. All three sites share common geologic characteristics: at each location, a shallow unconfined aquifer is contaminated and is suspected of contributing chemicals to a deeper confined aquifer. The intervening aquitard pinches out within the site boundaries, so proper mitigation of both aquifers depends on establishing whether and how contamination penetrated the aquitard, or whether contamination traveled around the aquitard and in which direction.

\section{Fort Ord Landfills, Fort Ord, California}

\section{Background}

Three landfills comprise about 100 acres within the northern portion of the former U.S. Army Fort Ord, near Monterey, California, as shown on Fig. 8. The main landfill was operated as a Class III facility from 1960 until 1987 and received household and commercial refuse and a small amount of chemical wastes. The primary concern for the site investigation centered on the presence of volatile organic compounds (VOCs) in soil and groundwater (Dames \& Moore 1991). VOCs were detected in lower aquifer wells in 1985, so the travel time from the landfills, if they were indeed the source, was less than 25 years.

\section{Geologic and hydrogeologic factors}

The Salinas Valley aquiclude separating the upper and lower aquifers pinches out at the western edge of the site, so the two aquifers are interconnected locally. Groundwater flow in the upper aquifer is to the west and groundwater flow in the lower aquifer is to the east. The opposite flow direction in the lower aquifer is probably due to gradient reversal by pumping from the lower and other deeper aquifers from municipal wells to the east.

\section{Investigation methods}

A drilling program was completed to install upper and lower aquifer wells. One well was continuously cored through the aquitard and lower aquifer to assess the consistency of the aquitard and the extensiveness of clay stringers in the lower aquifer. Gamma, sonic, SP, and resistivity logging was completed in lower aquifer borings. Aquifer parameters were measured through laboratory hydraulic conductivity tests of the aquitard clay, slug tests in the upper and lower aquifer, and pumping tests in the upper and lower aquifer to assist in design of extraction wells. A time-domain electromagnetic (TDEM) 


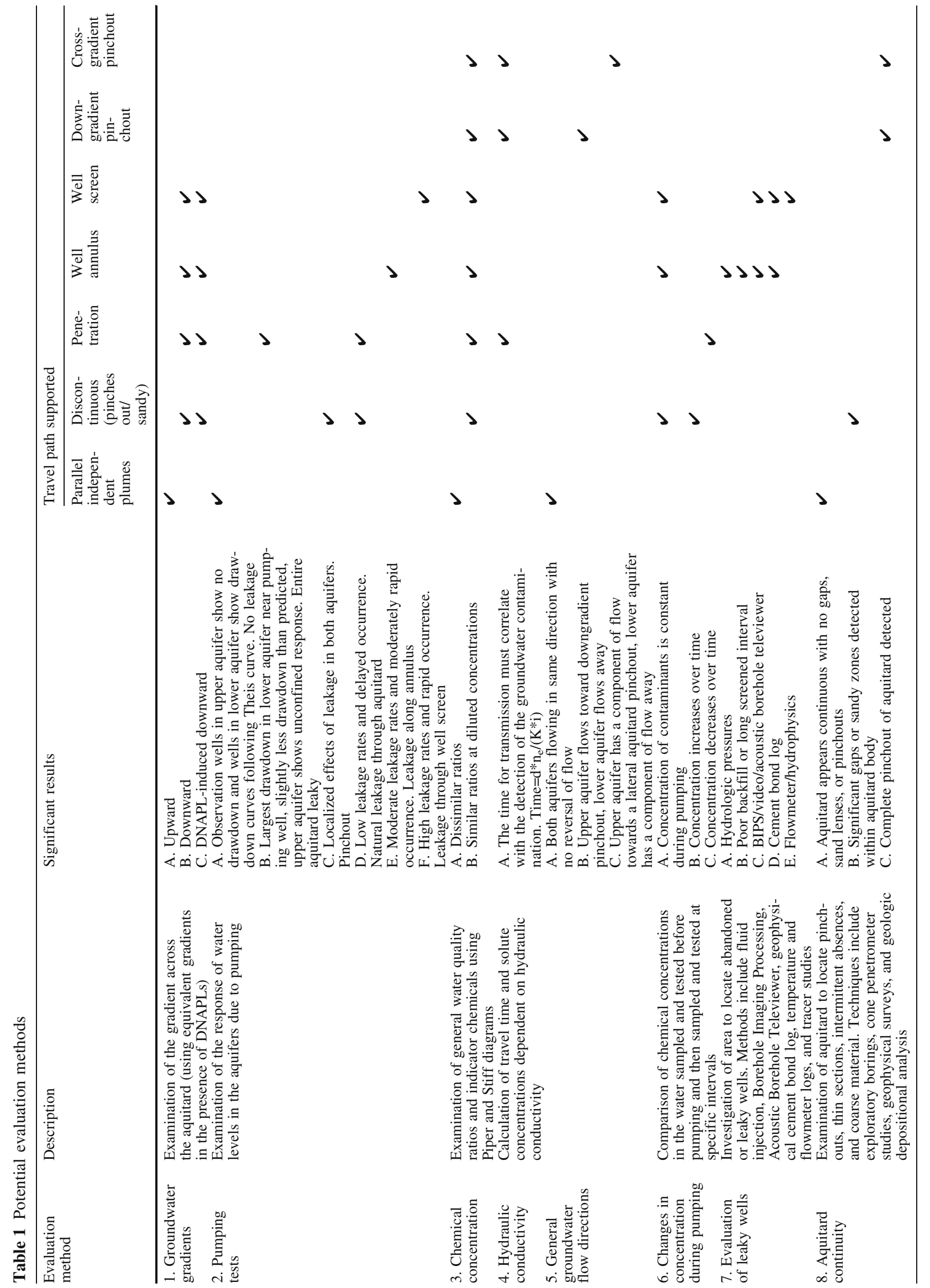




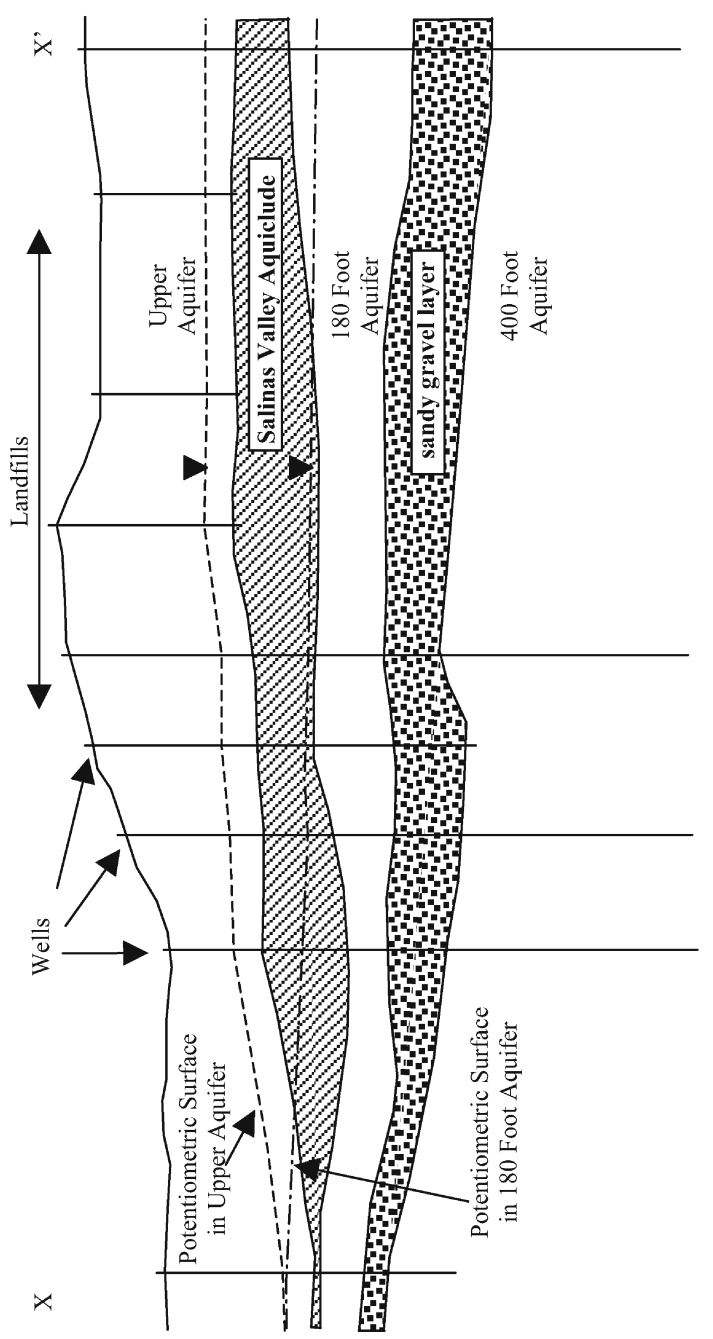

0
0
0
1
0
0
0
0
$z$
0
0
0
0
0
$n$
0
0
0
0
0
0
0
0
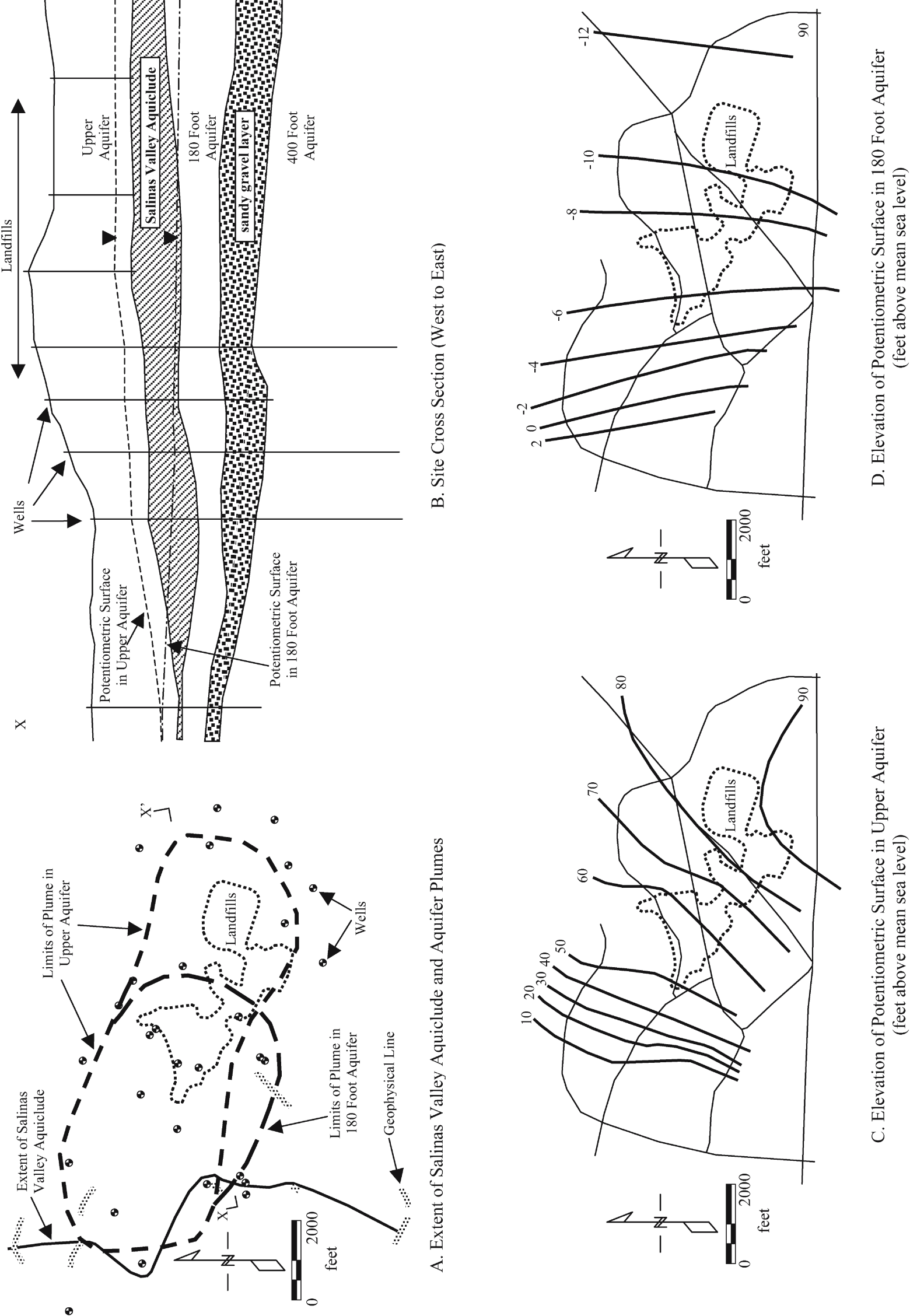

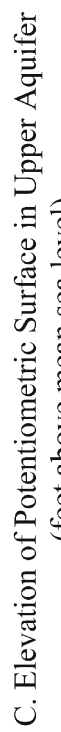


Table 2 Summary of evaluation methods for Fort Ord site

\begin{tabular}{|c|c|c|c|c|c|}
\hline $\begin{array}{l}\text { Evaluation } \\
\text { method }\end{array}$ & Description & $\begin{array}{l}\text { Discontinu- } \\
\text { ous (pinches } \\
\text { out/sandy) }\end{array}$ & $\begin{array}{l}\text { Pene- } \\
\text { tration }\end{array}$ & $\begin{array}{l}\text { Down- } \\
\text { gradient } \\
\text { pinchout }\end{array}$ & Summary of analysis \\
\hline $\begin{array}{l}\text { 1. Groundwater } \\
\text { gradients }\end{array}$ & D. Downward & $\boldsymbol{x}$ & $\boldsymbol{x}$ & & $\begin{array}{l}\text { Downward gradient induces downward movement } \\
\text { of contaminants through the aquitard. Analysis under } \\
\# 4 \text { below shows that the rate is too slow to be a } \\
\text { probable source of contamination. Continuous coring } \\
\text { of aquitard in vicinity of landfills indicates thick clay } \\
\text { with few sand lenses }\end{array}$ \\
\hline $\begin{array}{l}\text { 2. Pumping } \\
\text { tests }\end{array}$ & & $?$ & $?$ & & $\begin{array}{l}\text { Pumping test in lower aquifer did not show significant } \\
\text { leakage. Two upper aquifer wells monitored during } \\
\text { pumping of lower aquifer did not show clear response } \\
\text { to pumping (one well showed no response, the second } \\
\text { showed steady decline, continuing for } 30 \mathrm{~h} \text { after } \\
\text { pumping stopped) }\end{array}$ \\
\hline $\begin{array}{l}\text { 4. Hydraulic } \\
\text { conductivity }\end{array}$ & $\begin{array}{l}\text { B. The time } \\
\text { for transmission } \\
\text { calculation }\end{array}$ & $\boldsymbol{x}$ & $\boldsymbol{x}$ & $\checkmark$ & $\begin{array}{l}\text { Calculated travel time (advection only) for each unit: } \\
\text { Upper aquifer, landfills to pinchout }=2-11 \text { years } \\
\text { Aquitard, through } 50 \text { foot thickness }=17 \times 10^{3}-22 \times 10^{3} \\
\text { years } \\
\text { Lower aquifer, pinchout to center of plume }=400-1,700 \\
\text { years } \\
\text { Contamination was detected within } 25 \text { years, setting } \\
\text { an upper limit on total travel time } \\
\text { These results imply that travel through the aquitard } \\
\text { is unlikely. Travel from the landfills to the pinchout } \\
\text { is rapid, but the low gradient in the lower aquifer } \\
\text { slows movement. It is strongly possible that chemicals } \\
\text { crossed the ragged pinchout and then spread in the } \\
\text { lower aquifer by diffusion }\end{array}$ \\
\hline $\begin{array}{l}\text { 5. General } \\
\text { groundwater } \\
\text { flow directions }\end{array}$ & $\begin{array}{l}\text { B. Upper aquifer } \\
\text { flows toward } \\
\text { downgradient } \\
\text { pinchout, lower } \\
\text { aquifer flows } \\
\text { away }\end{array}$ & & & $\checkmark$ & $\begin{array}{l}\text { Groundwater levels measured on two different occasions } \\
\text { show case B }\end{array}$ \\
\hline $\begin{array}{l}\text { 8. Aquitard } \\
\text { continuity }\end{array}$ & $\begin{array}{l}\text { C. Complete } \\
\text { pinchout of } \\
\text { aquitard detected }\end{array}$ & & & $\checkmark$ & $\begin{array}{l}\text { Downgradient pinchout of aquitard identified in three } \\
\text { TDEM lines and five well borings }\end{array}$ \\
\hline
\end{tabular}
a ?, test is inconclusive for identifying contaminant travel path; $\boldsymbol{x}$, test assists in eliminating specific travel path; $\boldsymbol{V}$, test supports a specific
travel path

geophysical investigation was completed to delineate aquitard pinchout.

\section{Potential travel paths}

Based on the site history and local stratigraphy determined from the site investigation, three potential travel paths of contamination are identified:

1. A discontinuous aquitard could allow mingling of water from both aquifers and potential VOC transfer where the aquitard is missing.

2. VOCs could penetrate the aquitard, particularly in areas where it thins.

3. The downgradient merging of plumes at the aquitard pinchout could allow VOCs to enter the lower aquifer from the upper aquifer.

Fig. 8 Maps and cross-sections from the Fort Ord, California site

\section{Likely travel path}

Table 2 summarizes the analysis of potential travel paths. Drilling and sampling of the Salinas Valley Aquiclude indicates that it is on the order of 50 feet $(15 \mathrm{~m})$ thick and contains few sand lenses in the vicinity of the landfills. Calculated travel times for contaminants to penetrate the aquiclude are on the order of thousands of years. Based on these indications of the nature of the aquiclude, the potential travel pathways through the aquiclude (based on discontinuities or penetration) are eliminated from further consideration.

A downgradient pinchout of the aquiclude was delineated using boring and geophysical data, and groundwater flow directions and calculated travel times for contaminant transport around the pinchout are reasonable. While not irrefutable, these lines of evidence support the conclusion that the lower aquifer was contaminated by travel around the pinchout. Evidence of aquitard pinchout and groundwater flow directions implies that parallel independent plumes in each aquifer are unlikely. 


\section{Mid-Western U.S. site}

\section{Background}

This site is an industrial manufacturing plant covering over 100 acres (40 hectares), shown on Fig. 9. Approximately 15 years after beginning operations, Trichloroethylene (TCE) was detected in a municipal water well in the lower aquifer southeast of the site.

Two events at the site may have contributed to groundwater contamination. First, an improperly lined surface impoundment was constructed on the southeast corner of the site. The impoundment accepted wastewater for the first eight years of operation. Next, a spill occurred on the north side of the plant, eight years after beginning operations, resulting in the loss of several thousand gallons of TCE. TCE was detected in the upper aquifer in the vicinity of both of these sources, and at several locations in the lower aquifer. A distinction between contamination resulting from the surface impoundment and the spill was important for cleanup and liability reasons.

\section{Geologic and hydrogeologic factors}

The clay confining unit separating the upper and lower aquifers pinches out to the north and east of the site, allowing commingling of water from both aquifers. The clay contains local sand lenses that affect its ability to retard vertical movement of groundwater from the upper to lower aquifers. Previous studies indicate significant vertical leakage through the unit. Supporting evidence includes the following:

- shallow cone of depression in the lower aquifer compared to the pumping rate,

- digital flow model that requires a $20 \%$ leakage factor to simulate observed water levels in the lower aquifer (however, this leakage may come from a nearby stream, located beyond where the two aquifers merge),

- difference in hydraulic head between the two aquifers indicating a downward driving force, and

- anomalies in the normal geothermal field as indicated by geophysical temperature logs.

\section{Investigation methods}

Over 80 borings were drilled at the site, 37 of which were converted to monitoring wells. Wells were monitored quarterly to obtain water levels and samples for analysis. A constant-rate aquifer pumping test was performed in the lower aquifer to evaluate hydraulic parameters, including possible leakage through the clay. Downhole gamma logging was used in several borings to characterize the subsurface, and a TDEM geophysical survey was completed to delineate aquitard pinchout.

\section{Potential travel paths}

Four potential routes of cross-contamination were identified:
1. Contamination traveled toward the north in the upper aquifer, in the direction of greatest groundwater velocity. At the aquitard pinchout, the contamination entered the lower aquifer and then traveled southeast toward the city well. This route is supported by detections of contamination in lower aquifer wells northwest of the site, but refuted by clean lower aquifer wells northwest of the city well.

2. Contamination traveled to the northeast from the pond area to the northeastern aquitard pinchout, and then entered the lower aquifer. This pathway is supported by detection of contamination in a shallow well near the pinchout. No wells were installed in the lower aquifer between the northeastern pinchout and the city well.

3. Contamination leaked through the confining unit into the lower aquifer.

4. Contamination traveled down from the upper to the lower aquifer via well casing in the city well. At the time this data was collected, the city had not provided records of well construction for their well.

\section{Likely travel path}

Table 3 summarizes the analysis of potential travel paths. Using measured groundwater gradients and hydraulic conductivity values, the fastest travel path for contamination ( 1.5 years) is from the impoundment around the aquitard pinchout to the west (crossgradient). Travel from either source around downgradient or crossgradient pinchouts is also possible, although slightly slower (4.56.3 years). Based on the available evidence, it is not possible to conclusively identify which source contaminated the city wells, although the impoundment could have contaminated the wells sooner than the spill.

Travel through the aquitard is significantly slower (3274 years, depending on the location of penetration), even if a free-phase TCE is assumed to have ponded on top of the aquitard (minimum time of 14-29 years, depending on TCE saturation). For this reason, supported by drilling observations of continuous clay throughout the aquitard, penetration of the aquitard by TCE is not considered a likely pathway. Evidence of aquitard pinchout and groundwater flow directions implies that parallel independent plumes in each aquifer are unlikely.

\section{City of Merced, California}

\section{Background}

The City of Merced, California identified a regional Tetrachloroethylene (PCE) plume in several of their drinking water wells in 1987, shown on Fig. 10. Several sources were identified, mostly consisting of dry-cleaning establishments (five inactive establishments and six active ones), which had been in operation between 10 and 50 years preceding the discovery of PCE in lower drinking water aquifers. 


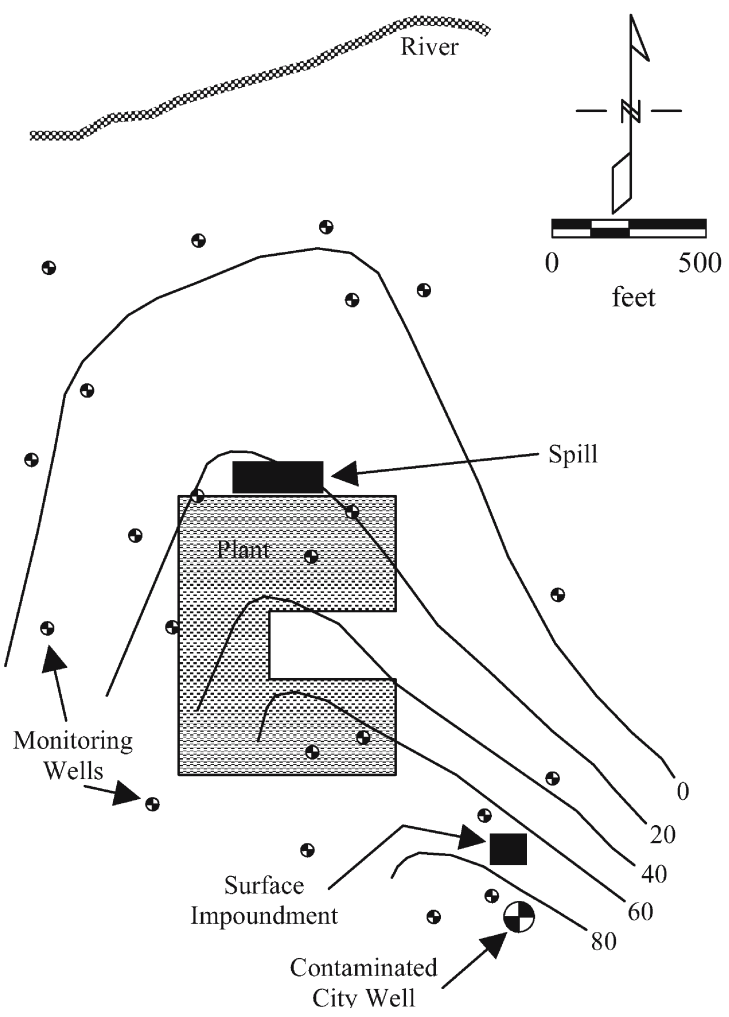

A. Thickness of Aquitard Clay (in feet above mean sea level)

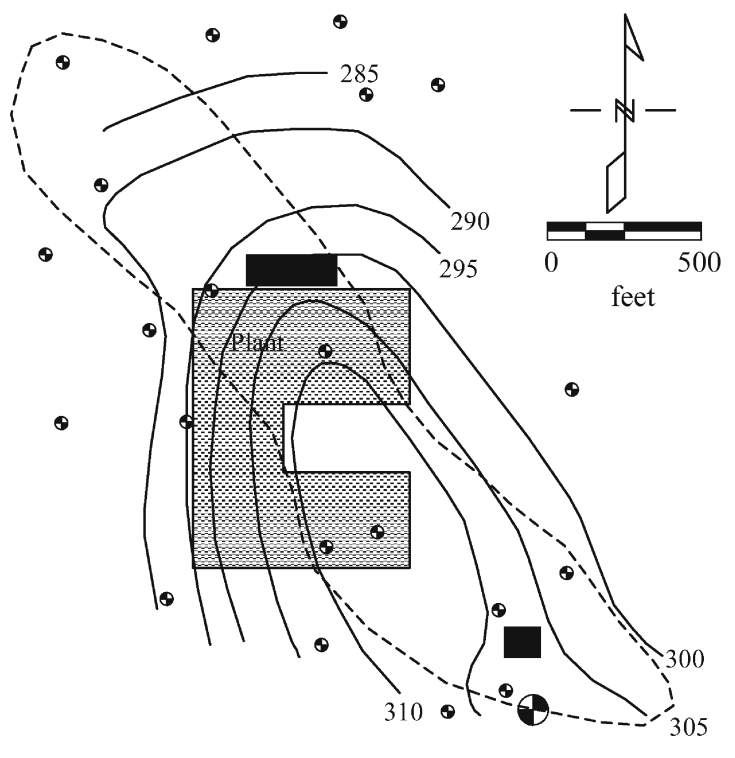

B. Elevation of Potentiometric Surface in Upper Aquifer (solid lines, in feet above mean sea level). Extent of TCE plume in Upper Aquifer (dashed line). Upper aquifer wells are shown.

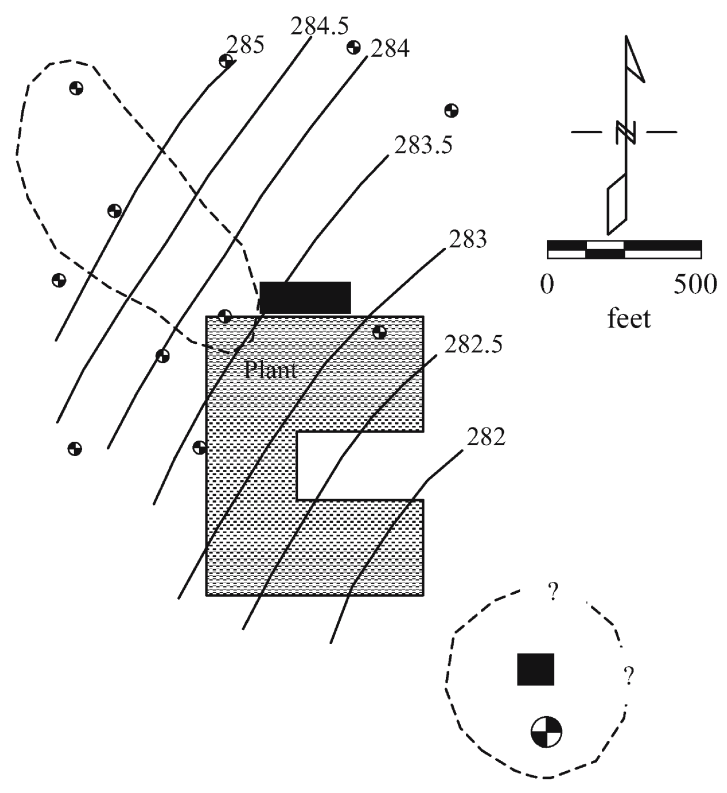

C. Elevation of Potentiometric Surface in Lower Aquifer (solid lines, in feet above mean sea level). Extent of TCE plume in Lower Aquifer (dashed lines). Lower aquifer wells are shown.

Fig. 9 Maps from the Mid-Western U.S. site 
Table 3 Summary of evaluation methods for Mid-West U.S. site

\begin{tabular}{|c|c|c|c|c|c|c|}
\hline $\begin{array}{l}\text { Evaluation } \\
\text { method }\end{array}$ & Description & $\begin{array}{l}\text { Discon- } \\
\text { tinuous } \\
\text { (pinches } \\
\text { out/sandy) }\end{array}$ & $\begin{array}{l}\text { Pene- } \\
\text { tration }\end{array}$ & $\begin{array}{l}\text { Down- } \\
\text { gradient } \\
\text { pin- } \\
\text { chout }\end{array}$ & $\begin{array}{l}\text { Cross- } \\
\text { gradient } \\
\text { pin- } \\
\text { chout }\end{array}$ & Summary of analysis \\
\hline
\end{tabular}

\begin{tabular}{lll}
\hline $\begin{array}{l}\text { 1. Groundwater } \\
\text { gradients }\end{array}$ & $*$ Downward & $\begin{array}{l}\text { Downward gradient induces downward movement } \\
\text { of contaminants through the aquitard. Analysis } \\
\text { under } \# 4 \text { below shows that the rate of penetration } \\
\text { through the aquitard is not fast enough for the } \\
\text { required time frame (15 years for the impoundment, } \\
7 \text { years for the spill). Drilling indicates continuous } \\
\text { clay with few sand lenses }\end{array}$
\end{tabular}

induced

downward

2. Pumping

tests

4. Hydraulic conductivity

\section{The time for transmission calculation}

Results are difficult to interpret (barometric pressure was not recorded, but could account for much of the noted water level fluctuation). Leakage into lower aquifer is indicated, but source of leakage is unclear (could be from upper aquifer or from nearby stream. Author's interpretation is that leakage is inflow from stream) Calculated travel time (advection only) for each pathway, including travel through the lower aquifer to the city well:

downgradient path, from impoundment= $5.4-5.8$ years

downgradient path, from spill $=5.3-6.3$ years crossgradient path, from impoundment $=1.5$ years crossgradient path, from spill $=4.5$ years through aquitard, near impoundment $=74$ years (29 years if free-phase TCE ponded above aquitard)

through aquitard, near spill $=32$ years $(14$ years if free-phase TCE ponded above aquitard) Contamination was detected within 15 years, setting an upper limit on travel time

These results imply that travel through the aquitard is unlikely. Travel via downgradient or crossgradient pathways is possible, with travel from the impoundment crossgradient being the shortest and fastest pathway

Groundwater levels measured on two different occasions show case B

Hearsay evidence suggests poor backfill around city well. Well construction logs had not been released by city at time of evaluation Downgradient and crossgradient pinchout of aquitard identified in six well borings and suggested as a possibility by the TDEM survey groundwater

flow directions

7. Evaluation

of leaky wells

8. Aquitard

continuity
B. Upper aquifer

flows toward

downgradient

pinchout, lower

away

B. Record of poor

backfill

C. Complete

pinchout of aquitard detected

${ }^{\text {a }}$ ?, test is inconclusive for identifying contaminant travel path; $\boldsymbol{*}$, test assists in eliminating specific travel path; $\boldsymbol{V}$, test supports a specific travel path

\section{Geologic and hydrogeologic factors}

Three contaminated aquifers have been identified in the region: a "shallow," unconfined aquifer, an "intermediate" semiconfined to unconfined aquifer, and a deeper "confined" aquifer (Walker 1989). The shallow and intermediate aquifers are separated by the "shallow clay" and the intermediate and confined aquifers are separated by the "Corcoran clay." Both clay units pinch out in the west part of the city, and the Corcoran clay has been noted to contain several sandy zones in this area (Elliott
1984). The intermediate and confined aquifers have a groundwater flow gradient to the east and the shallow aquifer has a local gradient to the west in the vicinity of the pinchouts (Elliott 1984; Walker 1989). The reversed gradient of the shallow aquifer in this area is probably due to recharge of the intermediate and confined aquifers in this location by shallow aquifer water. Downward gradients have been measured across both clay units (Walker 1989). 

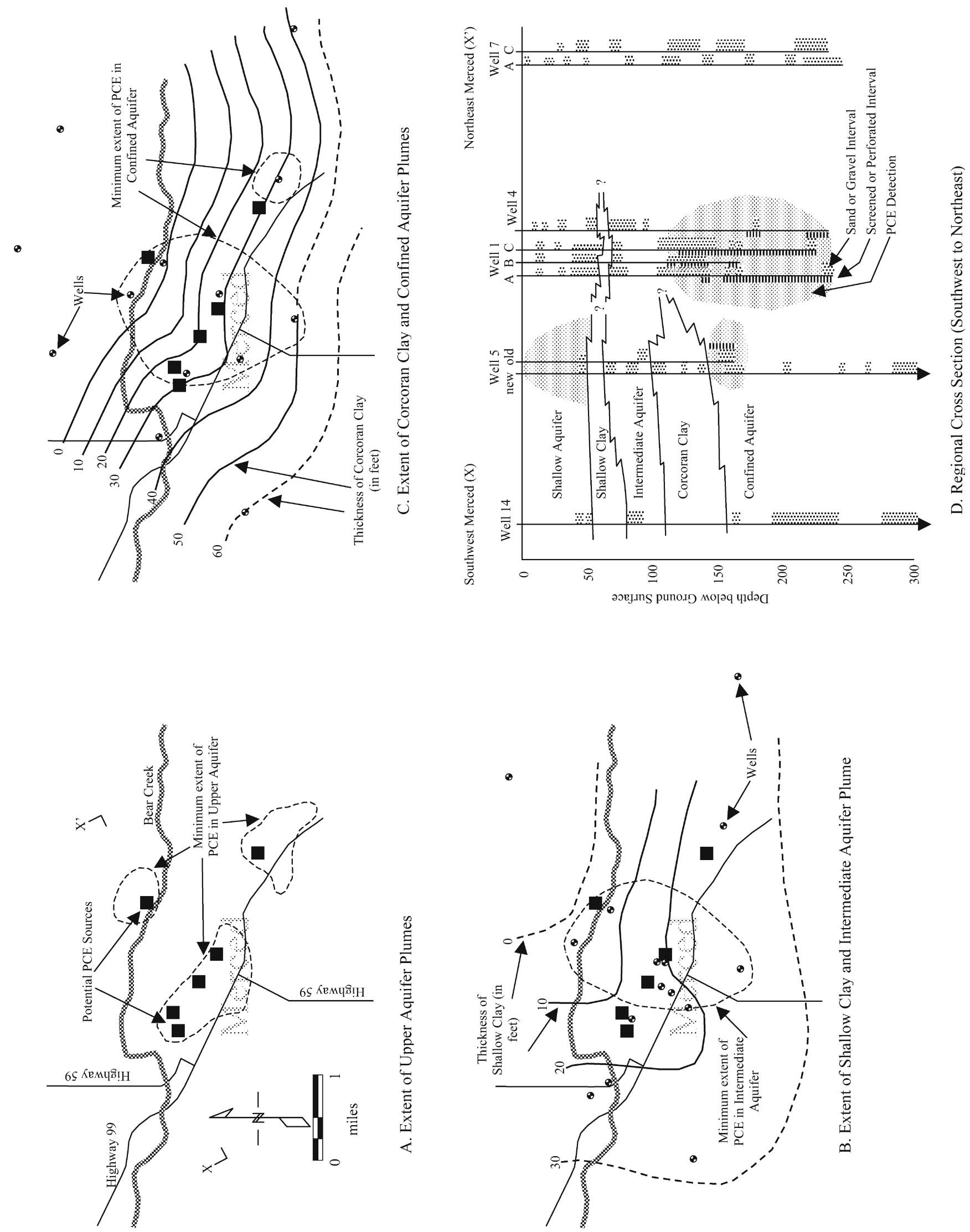

Fig. 10 Maps and cross-sections from the City of Merced, California site 
Table 4 Summary of evaluation methods for City of Merced site

\begin{tabular}{|c|c|c|c|c|c|c|c|}
\hline $\begin{array}{l}\text { Evaluation } \\
\text { method }\end{array}$ & Description & $\begin{array}{l}\text { Discon- } \\
\text { tinuous } \\
\text { (pinches } \\
\text { out/ } \\
\text { sandy) }\end{array}$ & $\begin{array}{l}\text { Pene- } \\
\text { tration }\end{array}$ & $\begin{array}{l}\text { Well } \\
\text { annulus }\end{array}$ & $\begin{array}{l}\text { Well } \\
\text { screen }\end{array}$ & $\begin{array}{l}\text { Upgra- } \\
\text { dient } \\
\text { pinchout }\end{array}$ & Summary of analysis \\
\hline
\end{tabular}

1. Groundwater G. Downward ? V Downward gradient induces downward
gradients

$\begin{array}{ll}\begin{array}{l}\text { 4. Hydraulic } \\ \text { conductivity }\end{array} & \begin{array}{l}\text { D. The time } \\ \text { for transmission } \\ \text { calculation }\end{array}\end{array}$

5. General D. Upper aquifer groundwater flows toward flow directions upgradient (in a regional sense) pinchout, and the intermediate and confined aquifers flow away

6. Changes in C. Concentration concentration decreases over time during pumping

7. Evaluation of leaky wells

B. Record of poor backfill or screened interval selection movement of contaminants through the aquitard. Analysis under \#4 below shows that the rate of penetration through the aquitard is fast enough for the required time frame (approximately 20 years) for the shallow clay, but not fast enough for the Corcoran clay

Calculated travel time (advection only) from source area in upper aquifer to plume in lower aquifer:

through shallow clay aquitard $=15$ years through Corcoran clay aquitard $=300$ years upgradient path, from source to intermediate of confined aquifer $=3-25$ years (depending on source location and specific aquifer conditions nearby)

Contamination was detected within 20 years, setting an upper limit on travel time. These results imply that travel through the aquitard or around the aquitard are both possible Flow direction information is from studies by the CVRWQCB and the USGS
Two different pumping-concentration tests
show decrease in PCE levels over time
(a drop from 20 to $1 \mathrm{ppb}$ over $24 \mathrm{~h}$ in the
first test and a drop from 53 to $23 \mathrm{ppb}$ over
$2 \mathrm{~h}$ in the second test)
The Central Valley RWQCB reports
improperly abandoned wells in the vicinity
Records of various city and private wells
indicate screens across both the intermediate
and confined aquifers and across the
Corcoran clay. City wells did not have
sanitary seals to the surface
Records of various city and private wells
indicate substantial sandy zones in the
Corcoran clay and complete upgradient
pinchout of both the shallow clay and
Corcoran clay

a ?, test is inconclusive for identifying contaminant travel path; $\boldsymbol{\varkappa}$, test assists in eliminating specific travel path; $\boldsymbol{V}$, test supports a specific travel path

\section{Investigation methods}

The region has been extensively characterized by individual site investigations, periodic sampling of city wells, and several regional and city-scale studies by the Central Valley Regional Water Quality Control Board (CVRWQCB; Walker 1988, 1989; Izzo 1989) and the U.S. Geological Survey (Elliott 1984). These studies include city well logs, hydrostratigraphic interpretations, inventories of impacted wells, soil gas surveys, and pumping concentration tests (Luhdorff \& Scalmanini 1987).

\section{Potential travel paths}

Five potential paths were identified for PCE to migrate from the shallow aquifer to the intermediate and confined aquifers:

1. The sandy intervals of the Corcoran clay allowed PCE migration into the confined aquifer.

2. Downward gradients allowed PCE to penetrate the clay units separating the aquifers.

3. PCE migrated down the annuluses of older water supply wells that did not have a surface sanitary seal or impermeable backfill. 
4. PCE migrated between aquifers through wells that were screened across more than one aquifer.

5. PCE migrated from the shallow aquifer to the intermediate and confined aquifers where all three are in contact west of the pinchouts of the clays that normally separate the aquifers.

\section{Likely travel path}

Table 4 summarizes the analysis of potential travel paths. Sandy zones identified in the Corcoran clay validate the potential of PCE penetrating the clay. Similarly, the downward groundwater gradients, used to calculate penetration rates, confirm that PCE could penetrate the Shallow clay within 15 years. Stratigraphic information confirming the pinchout of both clay layers, coupled with flow direction information in all aquifers and calculations of travel time show that PCE could have entered the lower aquifers from a flow path around the upgradient pinchouts of the clays. Finally, well construction records and information on well completions available in the technical literature indicate the PCE could travel down well annuluses or across aquifers via well screens.

In summary, none of the pathways could be eliminated, and quite likely all the pathways have contributed to some degree, considering the large number of sources, the size of the site, and the length of time involved. It was concluded that the best method to distinguish between the pathways would be a careful fingerprinting, statistical analysis or ratio analysis of contaminants from each source and from locations within each aquifer. Pumping tests did not prove to be effective in evaluating sources because there are too many interfering factors, including multiple water supply wells that would be in operation during the test and a site area too large to be evaluated with a single pumping well.

\section{Conclusions}

A number of tools to detect and evaluate pathways of aquifer cross-contamination were described, and then applied at three sites. Because the investigations for all three sites had been completed in the past, there was no opportunity to tailor the investigative elements to best identify pathways of cross-contamination. Nevertheless, several observations can be made on the quality of each tool:

1. In the absence of specially-designed investigative elements, calculations of water (and therefore contaminant) flow rates using hydraulic conductivity, gradient, and aquitard continuity information provided the strongest arguments for or against certain flow paths.

2. Evidence of aquitard pinchout or discontinuity (sandy intervals) strongly suggests certain flow paths, but must be coupled with other analysis tools to conclusively eliminate or confirm paths.
3. Similarly, evidence of leaky wells must be used in conjunction with other tests to establish their influence on cross-contamination.

4. Aquifer pumping tests are useful only if confounding factors (such as atmospheric pressure changes, leakage due to streams, and leakage from multiple locations) can be identified and accounted for in the interpretation.

While fingerprinting, statistical analysis or ratio analysis of contaminants from various sources and receptors was not completed for any of the evaluated sites, the authors believe that these techniques have strong potential for confirming or eliminating pathways. Future research in this area is suggested. Furthermore, the interpretation of pumping-concentration tests is not well defined and needs further assessment.

Acknowledgments Brian Aubry (currently of Geologica, Inc.) and Allison Remple developed the conceptual groundwater flow model at the Ft. Ord site. Julio Guerra of the City of Merced generously shared technical information on their regional PCE problem.

\section{References}

Abriola LM, Pinder GF (1985) A multiphase approach to the modeling of porous media contamination by organic compounds. 2. Numerical simulation. Water Resources Res 16:1926

Aller L (1984) Methods for determining the location of abandoned wells, EPA-600/2-83/123. US Environmental Protection Agency, Ada, Oklahoma

Alther GA (1979) A simplified statistical sequence applied to routine water quality analysis: a case history. Ground Water 17:556-561

Back W (1966) Hydrochemical facies and groundwater flow patterns in northern part of Atlantic coastal plain. Washington, DC, US Geol Surv Prof Pap 498-A

Bethune DN, Farvolden RN, Ryan MC, Guzman AL (1996) Industrial contamination of a municipal water-supply lake by induced reversal of ground-water flow, Managua, Nicaragua. Ground Water 34:699-708

Cardimona S, Clement WP, Kadinsky-Cade K (1998) Seismic reflection and ground penetrating radar imaging of a shallow aquifer. Geophysics 63:1310-1317

Clement WP, Cardimona S, Endres AL, Kadinsky-Cade K (1997) Site characterization at the groundwater remediation field laboratory. Lead Edge Nov:1617-1621

Dames \& Moore (1991) Remedial investigation report, Fort Ord landfills, Fort Ord, California, for U.S. Army Corps of Engineers. Dames \& Moore, Consult Rep

Douglas GS, McMillen S (1996) The stability and utility of diagnostic ratio hydrocarbon fingerprinting for soils contaminated with petroleum hydrocarbons, AAPG/SEPM Annu Meet Abstr 5:38-39

Elliott AL (1984) Ground-water conditions and shallow test-well information in the eastern half of Merced County, California, 1977-82. US Geol Surv Water Resources Inv Rep 83-4081

Farnham IM, Stetzenbach KJ, Singh AK, Johannesson KH (2000) Deciphering groundwater flow systems in Oasis Valley, Nevada, using trace element geochemistry, multivariate statistics, and geographical information system. Math Geol 32:943968

Faust CR (1985) Transport of immiscible fluids within and below the unsaturated zone: a numerical model. Water Resources Res 21:587-597 
Fetter CW (1999) Contaminant hydrogeology, 2nd edn. PrenticeHall, Upper Saddle River, New Jersey

Fryberger JS, Tinlin RM (1984) Pollution potential from injection wells via abandoned wells. In: Fairchild DM (ed) Proc 1st Natl Conf Abandoned Wells: Problems and Solutions. Environmental and Ground Water Institute, University of Oklahoma, Norman, Oklahoma, pp 84-117

Gass TE, Lehr JH, Heiss HW (1977) Impact of abandoned wells on ground water. US Environmental Protection Agency, Washington, DC, Rep EPA/600/3-77-095

Güler C, Thyne GD, McCray JE, Turner AK (2002) Evaluation of the graphical and multivariate statistical methods used for classification of water-chemistry data. Hydrogeol J 10:455-474

Izzo VJ (1989) Dry cleaners, a major source of PCE in the ground water. Central Valley Regional Water Quality Control Board Rep 19 September 1989

Jaquet JM, Froidevoux R, Verned JP (1975) Comparison of automatic classification methods applied to lake geochemical samples. Math Geol 7:237-265

Javandel I, Tsang CF, Witherspoon PA, Morganwalp D (1988) Hydrologic detection of abandoned wells near proposed injection wells for hazardous waste disposal. Water Resources Res $24: 261-270$

Kueper BH, Frind EO (1991) Two-phase flow in heterogeneous porous media. 2. Model application. Water Resources Res 27:1059-1070

Lacombe S, Sudicky EA, Frape SK, Unger AJA (1995) Influence of leaky boreholes on cross-formational groundwater flow and contaminant transport. Water Resources Res 31:1871-1882

Lin C, Pinder GF, Wood EF (1982) Water resources program, Princeton University, Princeton, New Jersey, Rep 83-WR-2

Lindenberg KA (1997) Down the drain: a ground penetrating radar (GPR) survey of a trichloroethylene (TCE)-contaminated site in Camben County, New Jersey. BSc Thesis, Princeton University, Princeton, New Jersey

Locke RA (1994) Immediate pumping effects on inorganic water chemistry and nitrate stratification in the Iowa River alluvial aquifer near Marengo, Iowa. MSc Thesis, University of Iowa, Iowa City, Iowa

Luhdorff \& Scalmanini (1987) Analysis of wells 3A, 3B, and 5, City of Merced, California. Luhdorff \& Scalmanini Consult Rep

Lusczynski NJ (1961) Head and flow in ground water of variable density. J Geophys Res 66:4247-4256
Mariner PE, Holzmer FJ, Jackson RE, White JE, Wahl AS, Wolf FG (1997) Fingerprinting arsenic contamination in the sediments of the Hylebos Waterway, Commencement Bay superfund site, Tacoma, Washington. Environ Eng Geosci 3:359-368

McCray JE, Falta RW (1997) Numerical simulation of air sparging for remediation of NAPL contamination. Ground Water 35:99_ 110

Meiri D (1989) A tracer test for detecting cross contamination along a monitoring well column. Ground Water Monitor Rev 9:78-81

Mercer JW, Cohen RM (1990) A review of immiscible fluids in the subsurface: properties, models, remediation, and characterization. J Contam Hydrol 6:107-163

Moore DJ (1991) The delineation of a surficial aquitard in Calvert City, Kentucky using electrical resistivity and borehole information. MSc Thesis, University of Kentucky, Lexington, Kentucky

Neuman SP, Witherspoon PA (1969) Theory of flow in a confined two-aquifer system. Water Resources Res 5:803-816

Neuman SP, Witherspoon PA (1972) Field determination of the hydraulic properties of leaky multiple-aquifer systems. Water Resources Res 8:1284-1298

Oolman T, Godard ST, Pope GA, Jin M, Kirchner K (1995) DNAPL flow behavior in a contaminated aquifer. Ground Water Monitor Rev Fall, pp 125-137

Powers SE, Villaume JF, Ripp JA (1997) Multivariate analysis to improve understanding of NAPL pollutant sources. Ground Water Monitor Remed 17:130-140

Walker S (1988) Soil gas survey. Merced PCE Inv, Central Valley Regional Water Quality Control Board Memo, 8 August 8 1988, file AB1803

Walker S (1989) Well investigation program assessment report, City of Merced wells 3A, 3B, 5, 2A, and 2B. Central Valley Regional Water Quality Control Board Rep, 9 June 1989

Welenco (1995) Water and environmental geophysical well logs, 7th edn. 1. Technical information and data. Welenco, Inc., Bakersfield, California

Williams RE (1982) Statistical identification of hydraulic connections between the surface of a mountain and internal mineralized zones. Ground Water 20:466-478

Zemo DA, Bruya JE, Graf TE (1995) The application of petroleum hydrocarbon fingerprint characterization in site investigation and remediation. Ground Water Monitor Remed 15:147-156 